\title{
PEGEMBANGAN POTENSI WISATA MELALUI OPTIMALISASI PERAN KELOMPOK SADAR WISATA (POKDARWIS) DESA ARJANGKA
}

\author{
Immy Suci Rohyani ${ }^{1 *}$, Isnan Nursalim²), Nur Suci Armini ${ }^{3 *}$ \\ 1)Fakultas Matematika Dan Ilmu Pengetahuan Alam, Universitas Mataram \\ 2)Program Studi Sosiologi, Universitas Mataram \\ 3)Fakultas Pertanian, Universitas Mataram
}

Jalan Majapahit Nomor 62, Kota Mataram, Provinsi Nusa Tenggara Barat

*)alamat korespondensi : immysuci@yahoo.co.id

\begin{abstract}
ABSTRAK
Perkembangan Pariwisata di Nusa Tenggara Barat saat ini menunjukan peningkatan yang signifikan. Saat ini pemerintah Provinsi Nusa Tenggara Barat melalui Dinas Pariwisata juga tengah fokus mengembangkan 99 Desa Wisata prioritas yang ada. Pesatnya perkembangan Pariwisata yang ada didukung oleh beberapa Desa yang ada di Nusa Tenggara Barat yang memiliki potensi disektor pariwisata. Pariwisata menjadi sektor prioritas pembangunan untuk menjadi mesin penggerak ekonomi di Nusa Tenggara Barat khususnya Pulau Lombok. Salah satunya yaitu Desa Arjangka, Kecamatan Pringgarata, Kabupaten Lombok Tengah. Desa Arjangka memiliki beberapa potensi wisata diantaranya adalah landscape berupa alam pedesaan yang indah, aktifitas sosial dan kerajinan masyarakat yang kesemuanya dapat dikemas menjadi paket-paket wisata yag menarik. Perlu adanya upaya optimalisasi kegiatan wisata di desa Arjangka, hal pertama yang harus benahi adalah pokdarwis yang berperan sanngat penting sebagai mesin penggerak aktifitas wisata di desa. Upaya Tim pelaksana kegiatan pengabdian kepada masyarakat untuk mencapai tujuan tersebut adalah melakukan Sosialisasi dengan mendatangkan pemateri dari Desa Wisata Masmas yaitu Habibburohman selaku penggerak Desa Wisata Masmas untuk berbagi pengalamannya dan menyusun strategi dalam membangun desa wisata Masmas. Sosialisasi yang diikuti oleh 25 Peserta mulai dari unsur pemerintah Desa Arjangka, Pemuda hingga tokoh Masyarakat ini memberikan inspirasi baru bagi Desa Arjangka untuk membangun Desa Wisata dengan memanfaatkan potensi yang sudah ada.
\end{abstract}

Kata Kunci : Desa Arjangka, Desa Wisata, Pokdarwis

\section{PENDAHULUAN \\ Desa Arjangka merupakan} salah satu dari 11 desa yang berada di
Kecamatan Pringgarata, Kabupaten Lombok Tengah, Provinsi Nusa Tenggara Barat. Kecamatan Pringgarata memiliki beberapa destinasi wisata yang sudah 
berkembang diantanya yaitu desa Pringgarata yang memiliki destinasi berupa River Tubing, Pasar Pancingan di Bilebante, dan Pesona Alam desa wisata Sepakek. Lokasi desa Arjangka yang berdekatan dengan destinasi wisata yang sudah ada bisa dikembangkan menjadi destinasi wisata baru sebagai lokasi pariwisata alternatif bagi wisatawan yang berkunjung ke Pringgarata.

Desa Arjangka merupakan desa hasil pemekaran dari Desa Pringgarata untuk mempercepat optimalisasi pelayanan kepada masyarakat sehingga segala kebutuhan masyarakat dapat diakomodir dengan baik. Setelah terjadinya pemekaran, Desa Arjangka terdiri dari 10 wilayah dusun, Puspalaya, Puspalaya Timur, Dasan Suman, Arjangka Utara, Dasan Lauk, Arjangka Selatan, Kubur Jaran Utara, Kubur Jaran Selatan, Jabon Utara, dan Jabon Tengah

Potensi terbesar yang dimiliki oleh Desa Arjangka terdapat pada sektor pertanian, dengan luas lahan persawahan sekitar 1000 Ha membuat mayoritas penduduk setempat berpofesi sebagai petani. Desa Arjangka memiliki bentang alam yang indah dengan latar belakang area persawahan yang juga potensial untuk dikelola sebagai bagian dari aktivitas wisata. Desa Arjangka memiliki potensi agrowisata berupa area persawahan dan budidaya jamur tiram. Masyarakat Desa Arjangka sangat ramah, aktivitas masyarakat selain sebagai petani juga sebagai pengerajin pisau tradisional. Bentang alam yang indah dan aktivitas keseharian masyarakat yang bersahaja dan tradisi yang masih terus terpelihara jika dikemas dengan baik dapat menjadi salah satu atraksi wisata untuk mengembangakan desa Arjangka sebagai desa wisata yang hasilnya dapat meningkatkan perekonomian dan kesejahteraan masyarakat setempat.

Pada saat ini, potensi wisata yang dimiliki Desa Arjangka masih belum dioptimalkan, kondisi ini diduga karean masih rendahnya kesadaran masyarakat terhadap potensi yang ada, masih kurangnya pendukung dari pemerintah desa setempat. Kesadaran masyarakat dan dukungan dari pihak desa sangat berperan penting untuk mengoptimalkan potensi wisata yang dimiliki Desa Arjangka, dan keduanya harus berjalan beriringan.

Upaya optimalisasi potensi desa Arjangka dalam pengembangan sektor pariwisata, perlu dilakukan langkah-langkah kongkret seperti mengidentifikasi potensi-potensi strategis dan pengembangan wisata desa Arjangka, memberikan pemahaman terhadap masyarakat setempat akan adanya potensi dalam sektor pariwisata yang dimiliki Desa Arjangka dan manfaatnya untuk masyarakat setempat. Selain itu juga perlunya kerjasama antara pihak pemerintah desa dengan masyarakat untuk memfasilitasi keperluan pendukung guna mengembangkan potensi wisata di Desa Arjangka.

Berdasarkan identifikasi masalah yang dilakukan diketahui bahwa permasalahan utama yang dihadapi dalam upaya penggembanagn desa Arjangka sebagai desa wisata adalah belum maksimalanya peranan pemuda yang 
tergabung dalam kelompok sadar wisata (Pokdarwis). Selain itu Pokdarwis juga kurang mendapatkan dukungan dari pemerintahan desa sehingga potensi yang ada tidak bisa dimanfaatkan dengan baik.

Berkenaan dengan situasi
tersebut maka perlu dilakukan optimalisasi peranan dan keberadaan dari Pokdarwis agar dapat berjalan secara maksimal, sehingga pengembangan potensi wisata yang ada di desa Arjangka dapat berjalan maksiamal dan berkelanjutan.

\section{tersebut maka perlu dilakukan}

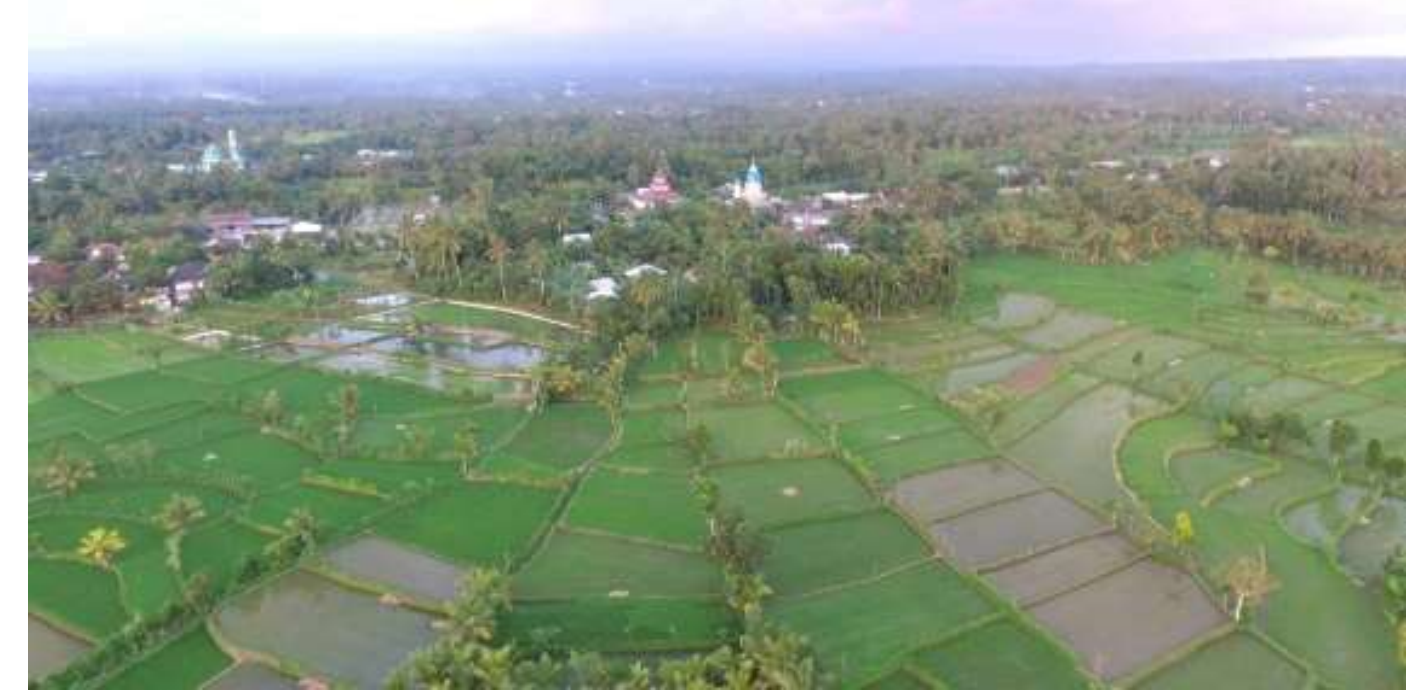

Gambar 1. Panorama Persawahan Desa Arjangka

\section{METODE KEGIATAN}

Berdasarkan

identifikasi

masalah yang ada Desa Arjangka, perlu adanya upaya pengembangan potensi yang dimiliki Desa Arjangka dengan mengoptimalkan Pokdarwis (Kelompok Sadar Wisata). Pokdarwis yang ada di Desa Arjangka belum berjalan secara optimal menjadi motor penggerak dalam aktivitas wisata di Desa Arjangka. Sehingga perlu dioptimalkan dan diaktifkan untuk memunculkan Desa Wisata yang unggul.

Metode yang digunakan untuk identifikasi masalah peran pokdarwis diantaranya adalah wawancara, observasi dan dokumntasi, sedangkan untuk optimalisasi peran Pokdaswis dilakukan sosialisai denga mendatangkan praktisi yang diharapkan dapat membuka wawasan dan menumbuhkan semangat anggota pokdarwis, dilakukan juga study banding ke desa-desa yang sudah mengembangkan aktivitas wisata dan selanjutnya dilakukan identifikasi potensi, menyusun paket-paket wisata dan promosi desa wisata.

\section{HASIL DAN PEMBAHASAN}

\begin{tabular}{llr}
\multicolumn{2}{c}{ Kegiatan pengabdian kepada } \\
masyarakat ini dimulai dengan \\
melakukan Survei lokasi dan
\end{tabular}


identifikasi untuk mengetahui potensipotensi yang ada di desa maupun masyarakat dan permasalahan yang ada di Desa Arjangka. Selanjutnya setelah dilakukan identifikasi potesni dan permasalahan kemudian di susun rumusan terkait potensi dan skala prioritas penyelsaian masalah yang di desa Arjangka.

Setelah mengetahui potensi dan permasaalahan yang ada maka diputuskan prioritas masalah utama yang harus dibenahi adalah Pokdarwis, melalui optimalisasi peran pokdarwis sebagai penggerak pariwisata desa dengan memberikan pemahaman dan pengetahuan dalam mengembangkan desa wisata, tim pelaksana pengabdian kepada masyarakat mengadakan kegiatan Sosialisasi mengenai peran pokdarwis dan potensi wisata di Desa Arjangka yang disampaikan oleh Habibburohman salah seorang penggerak wisata di Desa Mas Mas. Habibburohman berbagi pengalaman suka dan duka dalam membangun desa wisata Mas Mas. Sosialisasi yang diikuti oleh 25 Peserta mulai dari unsur pemerintah Desa Arjangka, Pemuda hingga tokoh Masyarakat ini memberikan inspirasi baru bagi Desa Arjangka untuk membangun Desa Wisata dengan memanfaatkan potensi yang sudah ada.

Kegiatan sosialisasi yang dilakukan kepada pokdarwis dan masyarakat memberikan perspektif dan pengetahuan baru mengenai cara pandang masyarakat dalam mengembangkan potensi wisata yang sudah ada di desa Arjangka. Upaya meningkatkan pemahaman tersebut kemudain masyarakat dan Pokdarwis diajak melihat secara langsung aktivitas wisata supaya memiliki gambaran dalam membangun Desa Wisata.

Tim pelaksana pengabdian kepada masyarakat mengajak Masyarakat Desa Arjangka Untuk Studi Banding ke Desa Wisata Masmas. Pemilhan Desa wisata Masmas sebagai lokasi tujuan Studi Banding atas dasar hasil survey yang dilakukan oleh tim pelaksana pengabdian kepada masyarakat ke beberapa Desa wisata yang ada di Pulau Lombok dan desa Masmas dianggap paling tepat karean memiliki banyak kesamaan potensi baik secara lanscape maupun karakter masyarakat.

Study Banding ke Desa

Wisata Masmas diwakili oleh lima orang wakil dari pokdarwis dan masyarakat dari Desa Arjangka. Pemilihan lima masyarakat yang mengikuti studi banding ke Desa Wisata Masmas ini berdasarkan kontribusi dan peran mereka selama ini. Sehingga setelah mereka mengikuti Studi Banding, diharapkan dapat menerapkan dan mensosialisaikan kembali apa yang sudah didapatkan ke anggota pokdarwis maupun masyarakat di Desa Arjangka lainnya.

Hasil studi banding tersebut menumbuhkan kesadaran dan semangat Kelompok Sadar Wisata (Pokdarwis) dan masyarakat setempat untuk melihat potensi-potensi yang ada di desa Arjangka untuk ditawarkan menjadi paket-paket wisat yang bisa dinikmati oleh wisatawan yaitu dengan menampilkan panorama alam pedesaan Arjangka yang masih asri dan aktivitas keseharian masyarakat 
Desa Arjangka menjadi produk wisata yang menarik.

Tim

Pengabdian

Pelaksana

Kegiatan

melakukan

Kepada

Masyarakat

memperkenalkan potensi us

Arjangka dengan cara membuat Video

Profil Desa, Brosur dan

memperkenalkan potensi desa

Arjangka melalui Sosial Media. Selain

untuk memperkenalkan Desa

Arjangka, pembuatan Video Profil,

Media Sosial dan Brosur juga bertujuan sebagai alat untuk mempromosikan desa Arjangka.

Terlebih di era seperti saat ini tentu sangat berdampak untuk menyebarluaskan panorama wisata Desa Arjangka melalui media sosial.

$$
\text { Proses pembuatan }
$$

Video Profil Desa, Brosur Wisata dan Media Sosial dimulai dari Survei lokasi dan diskusi bersama masyarakat untuk membuat paket-paket wisata yang akan dijual. Selain itu Pelaksana Pengabdian Kepada Masyarakat juga melakukan pengambilan Video dan Foto yang akan digunakan sebagai bahan untuk membuat Video Profil Desa dan Brosur paket wisata.

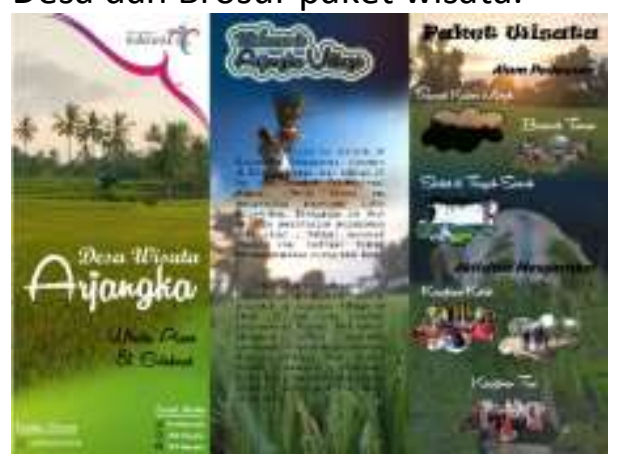

Gambar 2. Brosur Wisata Desa

$$
\text { Arjangka }
$$

Produk wisata yang sudah dikemas tersebut diuji coba dengan menawarkannya pada tamu mancanegara dan wisatwan lokal untuk mencoba segala jenis aktivitas masyarakat yang dikemas menjadi paket-paket wisata yang menarik merasakan sensasi liburan di Desa Arjangka. Wisatawan yang datang ke Desa Arjangka dipandu oleh tim pelaksana pengabdian kepada masyarakat dan pokdarwis serta Masyarakat Desa Arjangka.

Pertama wisatawan diajak untuk melihat dan belajar pembuatan tas dari bahan kain tenun. Selanjutnya wisatawan berjalan menuju pembuatan pisau khas Arjangka yang masih dibuat secara manual untuk melihat secara langsung proses pembuatannya sekaligus belajar membuat pisau. Selanjutnya wisatawan juga diajak untuk belajar sekaligus merasakan sensasi pembuatan Tas Ketak (Tas tradisional yang dibuat dari kain rotan)

Selepas melihat dan belajar beraneka ragam aktivitas keseharian masyarakat selanjutnya wisatawan menikmati panorama alam pesawahan desa Arjangka. Bukan hanya menikmati panorama alam pedesaan Arjangka saja melainkan wisatwan yang beragama Muslim juga melakukan Sholat di tengah sawah. Selepas itu wisatwan merasakan masakan khas Arjangka sekaligus menikmati panorama persawahan desa Arjangka.

Gejala pariwisata telah ada semenjak adanya perjalanan manusia dari suatu tempat ke tempat lain dan perkembangannya sesuai dengan sosial budaya masyarakat itu sendiri. Semenjak itu pula ada kebutuhan- 
kebutuhan manusia yang harus dipenuhi selama perjalanannya, di samping juga adanya motivasi yang mendorong manusia untuk memenuhi kebutuhan hidupnya. Meningkatnya peradaban manusia, dorongan untuk melakukan perjalanan semakin kuat dan kebutuhan yang harus dipenuhi semakin kompleks, membuat aktifitas wisata akan selalu diminati oleh masyarakat.

Menurut beberapa ahli, pariwisata telah dimulai sejak dimulainya peradaban manusia itu sendiri dengan ditandai oleh adanya pergerakan penduduk yang melakukan ziarah dan perjalanan agama lainnya, disamping juga digerakkan oleh perasaan lapar, haus, perasaan ingin tahu, perasaan takut, gila kehormatan, dan kekuasaan.

Dewasa ini pariwisata telah menjadi salah satu industri andalan utama dalam menghasilkan devisa di berbagai negara seperti Thailand, Singapura, Filipina, Fiji, termasuk Indonesia. Dengan pentingnya peranan pariwisata dalam pembangunan ekonomi berbagai negara, pariwisata sering disebut sebagai "passport to development", "new kind of sugar", tool for regional development, "invisible export", non-polluting industry" dan sebagainya (Pitana dan gayatri, 2002). Pariwisata

adalah alat pembangunan yang inklusif. Artinya pariwisata memungkinkan seluruh kelompok masyarakat untuk berkontribusi dalam menciptakan peluang, manfaat, dan partisipasi dalam pengambilan keputusan. (Ardika, 2018). Meningkatkan kesejahteraan masyarakat desa melalui pariwisata menjadi peluang yang sangat menjanjikan terlebih Desa Arjangka memiliki potensi Alam persawahan yang masih asri, aktivitas masyarakatnya yang unik, keramahtamahan masyarakatnya hingga tradisi masyarakat yang masih terjaga sampai saat ini. Pengelolaan yang baik dan tepat akan dapat mendatangkan manfaat yang besar baik bagi pendapatan desa, pelaku wisata maupun masyarakat Desa Arjangka

Menurut Hunziker dan Kraft dalam Muljadi (2012) pariwisata adalah keseluruhan jaringan dan gejala-gejala yang berkaitan dengan tinggalnya orang asing disuatu tempat dengan syarat orang tersebut tidak melakukan suatu pekerjaan yang penting (Major Activity) yang memberi keuntungan yang bersifat permanent maupun sementara.

Di dalam kamus besar bahasa Indonesia dikemukakan bahwa pariwisata adalah suatu kegiatan yang berhubungan dengan perjalanan rekreasi. Istilah pariwisata pertama kali digunakan pada tahun 1959 dalam Musyawarah Nasional Turisme II di Tretes, Jawa Timur. Istilah ini dipakai sebagai pengganti kata Turisme sebelum kata pariwisata diambil dari bahasa Sansekerta.

Pertumbuhan pariwisata sebagai industri belakangan ini menunjukkan grafik yang sangat meningkat dan bahkan mampu mendongkrak pertumbuhan ekonomi Indonesia semakin baik. Menurut definisi yang luas pariwisata adalah perjalanan dari satu tempat ke tempat 
lain,bersifat sementara, dilakukan perorangan maupun kelompok, sebagai usaha mencari keseimbangan atau keserasian dan kebahagiaan dengan lingkungan hidup dalam dimensi sosial, budaya, alam dan ilmu..

Pada dasarnya motiv kegiatan pariwisata itu adalah untuk mengisi waktu luang, untuk bersenang-senang, bersantai, studi, kegiatan Agama, dan mungkin untuk kegiatan olahraga. Selain itu semua kegiatan tersebut dapat memberi keuntungan bagi pelakunya baik secara fisik maupun psikis baik sementara maupun dalam jangka waktu lama.

Kepariwisataan dipandang sebagai sesuatu yang abstrak, misalnya saja sebagai suatu gejala yang melukiskan kepergian orang-orang didalam negaranya sendiri (pariwisata domestik) atau penyeberangan orangorang pada tapal batas suatu negara (pariwisata internasional). Pembangunan pariwisata daerah secara regional akan lebih mudah dilakukan melalui pengembangan pariwisatanya, terutama dalam menghadapi terjadinya gejala urbanisasi sebagai akibat semakin padatnya penduduk pada suatu kota yang sering menimbulkan masalah sosial dan ekonomi. Diharapkan dengan perkembangan pariwisata memberikan kenikmatan dan kepuasan pada wisatawan dan kemakmuran serta kesejahteraan bagi masyarakat lingkungannya.

Industri pariwisata adalah kumpulan usaha pariwisata yang saling terkait dalam rangka menghasilkan barang dan/atau jasa bagi pemenuhan kebutuhan wisatawan dalam penyelenggaraan pariwisata (Undang Undang Pariwisata no10 tahun 2009).

$$
\text { Di dalam menjalankan }
$$

perannya, industri pariwisata harus menerapkan konsep dan peraturan serta panduan yang berlaku dalam pengembangan pariwisata agar mampu mempertahankan dan meningkatkan jumlah kunjungan wisatawan yang nantinya bermuara pada pemberian manfaat ekonomi bagi industri pariwisata dan masyarakat lokal. Industri-industri pariwisata yang sangat berperan dalam pengembangan pariwisata adalah: biro perjalanan wisata, hotel dan restoran. Selain itu juga didukung oleh industri-industri pendukung pariwisata lainnya.

$$
\text { industri pariwisata dengan }
$$

industri yang dipahami secara umum sangat berbeda sekali, industri merupkan pengolahan barang yang belum jadi menjadi barang yang sudah jadi dan siap untuk digunakan. Sedangkan, Industri Pariwisata merupakan suatu industri dari serangkaian perusahan yang menghasilkan barang dan jasa yang diperuntukkan pada para wisatawan agar terpenuhi kesenangannya dalam berwisata.

Perencanaan pariwisata pada dasarnya ditujukan untuk memberikan manfaat sebesar besarnya bagi daerah tujuan wisata sekaligus meminimalisir dampak negatif dari proses dan hasil pengembangan pariwisata di daerah tersebut. Disisi lain pengembangan pariwisata yang harus berkesinambungan dan terus memberikan sumbangan bagi kesejahteraan dan kemaslahatan 
penduduk, serta seterusnya meningkatkan kualitas lingkungan serta melestarikan budaya setempat. (Soedibyo, 2005)

Disamping daya tarik wisata, wisatawan dalam melakukan kegiatan wisata juga membutuhkan adanya fasilitas yang menunjang perjalanan tersebut. pemenuhan kebutuhan perjalanan tersebut, perlu disediakan bermacam-macam fasilitas, mulai dari pemenuhan kebutuhan sejak berangkat dari tempat tinggal wisatawan, selama berada di destinasi pariwisata dan kembali ke tempat semula. "Attractions bring people to the destination; facilities service them when they get there. Because they are away from home,the visitor requires certain things a place to stay, something to eat and drink" (Mill, 1990).

\section{KESIMPULAN DAN SARAN}

Kegiatan Pengabdian Kepada
Masyarakat dengan Program
optimalisasi potensi wisata di Desa
Arjangka selama 45 hari ini berjalan
baik dan lancar. Upaya
mengoptimalisasikan potensi wisata
yang ada di Desa Arjangka diharapkan
masyarakat khususnya Pokdarwis
(Kelompok Sadar Wisata Desa
Arjangka) dapat menjalankan aktivitas
pariwisata di Desa Arjangka. Untuk
menjadi Desa Wisata yang unggul,
penataan lokasi dan penyediaan
fasilitas yang dapat menunjang
kemajuan disektor pariwisata harus
diperbaiki bersama.

Kegiatan Pengabdian Kepada Masyarakat dengan Program optimalisasi potensi wisata di Desa Arjangka selama 45 hari ini berjalan baik dan lancar. Upaya mengoptimalisasikan potensi wisata yang ada di Desa Arjangka diharapkan masyarakat khususnya Pokdarwis (Kelompok Sadar Wisata Desa Arjangka) dapat menjalankan aktivitas pariwisata di Desa Arjangka. Untuk menjadi Desa Wisata yang unggul, penataan lokasi dan penyediaan fasilitas yang dapat menunjang diperbaiki bersama.

\section{UCAPAN TERIMAKASIH}

Segenap tim pelaksana pengabdian kepada masyarakat dengan ini mengucapkan terimakasih banyak kepada LPPM Universitas Mataram yang telah memberikan kami kesempatan untuk melakukan kegiatan pengabdian kepada Masyarakat ini. Ucapan Terimakasih kepada Kepala Desa dan Masyarakat Desa Arjangka atas dukungan dan kerja samanya dalam menjalankan program Optimalisasi potensi wisata di Desa Arjangka. Selanjutnya ucapan terimakasih juga kami ucapkan kepada bapak Habiburahman yang sudah bersedia berbagi pengalaman dan motivasi kepada masyarakat.

\section{DAFTAR PUSTAKA}

Ardika IG. 2018. Kepariwisataan Berkelanjutan : Rintis Jalan Lewat Komunitas. Jakarta: PT Kompas Media Nusantara

Pitana IG, Gayatri GP. 2005. Sosiologi Pariwisata. Yogyakarta: Andi Offset

Soedibyo J. 2005. Bina Wisata Nusantara, Bentuk Partisipasi Masyarakat pada Pembangunan DaerahWisata. Jurnalpariwisata.com

Mill RC. 1990. The Tourism System. New Jarsle: Preticehall International

Muljadi. 2012. Kepariwisataan dan Perjalanan. Jakarta: PT. Raja Grafindo Persada. 